\title{
The Analysis of Factors That Affect Intention to Use on E-learning Users Using Technology Acceptance Model (TAM) Approach
}

\author{
Dila Fitriza Rulevy ${ }^{1, *}$ Ayu Aprilianti ${ }^{2}$
}

\author{
${ }^{1}$ Universitas Indonesia \\ ${ }^{2}$ Universitas Indonesia \\ *Corresponding author.Email: dilafitriza@gmail.com
}

\begin{abstract}
New form of learning that combines technology, called an e-learning revolution, has increased in recent years and is projected to increase more in the coming years. However, some research proved that most e-learning programs showed a higher failure rate than traditional learning methods. Technology addiction and its availability in the modern world, and the economic potential for organizations, make it essential to understand the factors that might lead to increase elearning adoption in the organizational context. This study will see employees' intention to use an e-learning by extending the Technological Acceptance Model (TAM) using some other related factors, such as goal orientation learning, management support, computer self-efficacy, and enjoyment. This study was conducted on 213 respondents in a company that owns e-learning using a questionnaire. Data obtained were analyzed using Structural Equation Modeling (SEM) using AMOS software. The results show that of the four variables, goal orientation learning and enjoyment have a significant positive effect on perceived ease of use and perceived usefulness, which acts as mediation towards the intention to use in the Technological Acceptance Model (TAM). In addition, an additional variable, which is satisfaction, proved a significant positive effect on the intention to use.
\end{abstract}

Keywords: Affect Intention to Use, E-Learning, Technology Acceptance Model.

\section{INTRODUCTION}

Volatility, Uncertainty, Complexity, and Ambiguity, commonly called VUCA, is a new concept describes the current state of the world, defined as a competitive digital economy environment [1] where organizations must adjust their previous structures in order to adapt to changes that are happening around [2]. Digital transformation is one of the main challenges, as an impact of VUCA throughout the industry today. Digital transformation involves adjusting between technology and business models to be more effective in engaging customers at each point of contact in a customer experience cycle.

Sustainable learning is an essential prerequisite for dealing with change and succeeding in building innovation [3]. This was also conveyed by [4], in [3], to improve a company's s ability to innovate and focus on development orientation, sustainable learning is the most crucial prerequisite. In practice, companies generally conduct training as one of a series of sustainable learning, which is a planned effort to facilitate training related to employee work, skills, and behavior [5].

The new form of learning that combines technology has increased in recent years and is projected to increase more in the coming years, described as an e-learning revolution [6] in [7]. E-learning is defined as various applications and processes that provide common features by relying on several computer technology types to promote learning [8]. E-learning is one of the outputs present in this digital transformation era, which is connecting employee learning with organizational development to adapt to digital transformation.

At present, Indonesia ranks 8th, with an increase of $25 \%$ annually for companies. The presence of e-learning can be said as a new breakthrough that is expected to facilitate the company's task in developing the capabilities of its employees. However, research has found that the implementation of e-learning consumes expensive investments for the company and shows a low 
level of use among users [9]. Most recent research shows that most e-learning programs show higher failure rates than traditional learning methods [10] in [9]. Reference [11] says that e-learning can be classified as a system, where the system is very user-oriented, that its successful implementation is often measured by learner satisfaction [12] in [9]. Therefore, companies must look at the factors that influence the success of e-learning in the company when the company wants to make changes to face digital transformation and continues to prioritize increasingly advanced technology-based learning.

To get an idea of the success of the implementation of e-learning, this study adopts the research that has been done before $[13,14]$ by looking at factors that affect intention to use on e-learning users using Technology Acceptance Model (TAM) approach. This study will use e-learning, with the Technological Acceptance Model (TAM) approach, using other related factors, such as goal orientation learning, management support, computer self-efficacy, and enjoyment. In addition, with previous studies conducted by [14], this study will also examine satisfaction as one of the other factors influencing the intention to use.

In 1989, Davis conducted research and developed the Technology Acceptance Model (TAM) that described the acceptance or rejection of a system [15]. TAM has three aspects: ease of use, perceived usefulness, and intention to use. This research will focus on several factors that have been investigated by [13] and [14], with these factors, including goal orientation learn- ing, management support, computer self-efficacy, and enjoyment that influence TAM. Learning goal orientation refers to individual motivation to increase their level of competence to facilitate improvement in task performance [16]. Reference [17] found that learning goal orientation was found to influence perceived ease of use positively. Fererence [13] found that there was a positive in- fluence between learning goal orientation on perceived ease of use and perceived usefulness. In this study, the two dimensions in the TAM will be tested.

(H1): There is a positive influence between learning goal orientation and perceived ease of use

(H2): There is a positive influence between learning goal orientation and perceived usefulness

Management support refers to feelings that individuals feel from the general support of management in e-learning provided, including encouragement and resource support [18]. Based on TAM, management support is an external variable for models that affect perceived usefulness and perceived ease of use [13].

(H3): There is a positive influence between management support and perceived ease of use
(H4): There is a positive influence between management support and perceived usefulness

Computer self-efficacy refers to confidence in a person's ability to mobilize the motivation, cognitive resources, and actions needed to meet particular situational demands [19]. There are many theoretical and empirical studies in the information technology literature that support that people with high computer self-efficacy will have a positive perception of how easy and useful a system [20-22,17] in [13].

(H5): There is a positive influence between computer selfefficacy and perceived ease of use

(H6): There is a positive influence between computer selfefficacy and perceived usefulness

Enjoyment refers to the extent to which activities that use the system are considered fun by someone regardless of the performance consequences that must be anticipated [15]. Researchers argue that enjoyment in using a system positively influences perceived ease of use [17, 23-25] in [13] and perceived usefulness $[26,23,17]$ in [13].

(H7): There is a positive influence between enjoyment and perceived ease of use

(H8): There is a positive influence between enjoyment and perceived usefulness

Reference [15] found that only perceived ease of use and perceived usefulness directly influenced intention to use the system [15]. Intention to use refers to individual subjective probability when they will show particular behavior [27]. Thus, the following hypothesis is proposed:

(H9): There is a positive influence between perceived ease of use and intention to use

(H10): There is a positive influence between perceived usefulness and intention to use

In addition, because users' expected behavior is to increase their intention to use e-learning, it is vital to see if they are satisfied with the system provided. Therefore, this study will try to find the effect of satisfaction on intention to use, where the more they are satisfied with the system, the higher their intention to use e-learning. Satisfaction refers to a benchmark that looks at the extent to which users perceive that the system they are using is targeting and serving their needs [28] in [14]. Satisfaction has been found to have a significant positive effect on the intention to use e-learning services in several studies [29 $-35]$

(H11): There is a positive influence between satisfaction and intention to use. 


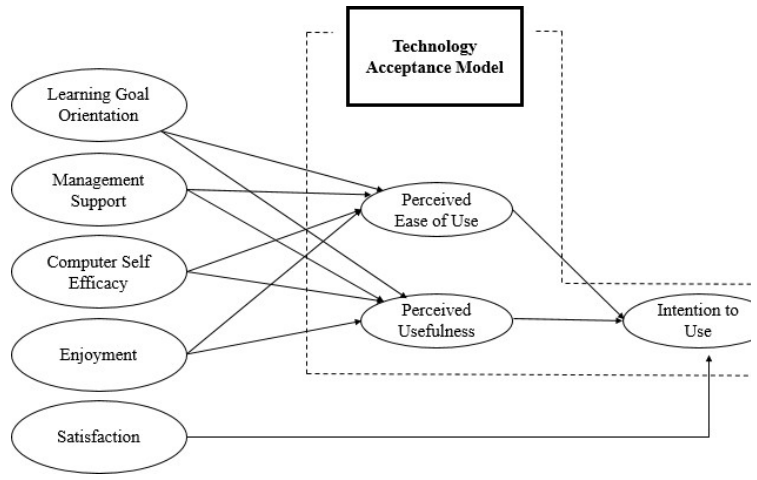

\section{METHODS}

\subsection{Sampling and data collection}

To collect the data, a questionnaire was structured with nine sections, where eight of them are the study's constructs, and one of them is the general characteristics of the respondents. All items were measured using six points Likert scale, ranging from 1 (totally disagree) to 6 (totally agree).

The respondents of this research come from one consumer goods company in Indonesia that has been using e-learning for several years and knows as a company that put development on top priority.

Validity and reliability of research instrument

The validity and reliability of research instruments were tested into two processes, pre-test, and main-test. Fifty-nine employees were asked to complete the questionnaire during the pre-test. During the pre-test, the questionnaire's validity was tested using the KaiserMeyer-Olkin (KMO), which could be declared valid if the KMO value was $\geq 0.5$ [36]. In testing the questionnaire's reliability, diagnostic measurements called reliability coefficients were carried out, where this coefficient looked at the over-all scale consistency through Cronbach alpha, which was considered reliable and accepted when the minimum value was 0.6 [36]. After testing the pre-test result's validity and reliability, three questions on computer self-efficacy were eliminated, and several questions were revised into a better translation.

During the main-test, a questionnaire was spread to four hundred and twenty-seven employees, and two hundred and twenty-four of them participated in this research. Finally, only two hundred and thirteen are eligible in this research, after testing the validation through factor loading, reliability through Construct Reliability (CR) and Average Variance Extracted (AVE) values that could be seen using AMOS software. The structural Equation Modeling (SEM) Approach was used to see the hypothesis testing of the researcH.

\section{RESULTS AND DISCUSSION}

After the data was collected, descriptive analysis was tested using SPSS. Table 1 below shows the respondent's demographics of the research.

Table 1 Respondent's demographics

\begin{tabular}{|c|c|c|c|}
\hline $\begin{array}{c}\text { Respondent' } \\
\text { s } \\
\text { Demographi } \\
\text { cs }\end{array}$ & Category & $\begin{array}{c}\text { Numb } \\
\text { er }\end{array}$ & $\begin{array}{c}\text { Percenta } \\
\text { ge }\end{array}$ \\
\hline \multirow[t]{2}{*}{ Gender } & Female & 108 & $51 \%$ \\
\hline & Male & 105 & $49 \%$ \\
\hline \multirow[t]{6}{*}{ Age } & $<23$ years & 8 & $4 \%$ \\
\hline & $>52$ years & 3 & $1 \%$ \\
\hline & $23-30$ years & 71 & $33 \%$ \\
\hline & $31-38$ years & 74 & $35 \%$ \\
\hline & $39-45$ years & 48 & $23 \%$ \\
\hline & $45-52$ years & 9 & $4 \%$ \\
\hline \multirow[t]{8}{*}{ Division } & $\begin{array}{l}\text { Communicati } \\
\text { on }\end{array}$ & 1 & $1 \%$ \\
\hline & CPD & 91 & $43 \%$ \\
\hline & $F \& A$ & 11 & $5 \%$ \\
\hline & HRD & 13 & $6 \%$ \\
\hline & LLD & 20 & $9 \%$ \\
\hline & PPD & 43 & $20 \%$ \\
\hline & R\&I & 2 & $1 \%$ \\
\hline & STRAD & 4 & $2 \%$ \\
\hline \multirow[t]{3}{*}{ Position } & Supply Chain & 27 & $13 \%$ \\
\hline & Manager & 139 & $65 \%$ \\
\hline & $\begin{array}{l}\text { Staff/Executo } \\
r\end{array}$ & 73 & $35 \%$ \\
\hline \multirow{5}{*}{$\begin{array}{l}\text { Years of } \\
\text { service }\end{array}$} & $<6$ months & 15 & $7 \%$ \\
\hline & $>6$ years & 56 & $26 \%$ \\
\hline & $1-3$ years & 64 & $30 \%$ \\
\hline & $3-6$ years & 62 & $29 \%$ \\
\hline & $\begin{array}{l}6 \text { monts }-1 \\
\text { years }\end{array}$ & 16 & $8 \%$ \\
\hline \multirow{4}{*}{$\begin{array}{c}\text { Average } \\
\text { frequency of } \\
\text { e-learning } \\
\text { usage }\end{array}$} & $\begin{array}{l}\text { Rare (1x per } \\
\text { month) }\end{array}$ & 112 & $53 \%$ \\
\hline & $\begin{array}{l}\text { Occasionally } \\
(2 x-3 x \text { per } \\
\text { month) }\end{array}$ & 76 & $36 \%$ \\
\hline & $\begin{array}{l}\text { Often }(>3 x \\
\text { per month })\end{array}$ & 18 & $8 \%$ \\
\hline & Never & 7 & $3 \%$ \\
\hline
\end{tabular}

Table 2 below shows the instruments' validity and reliability, and table 3 shows the hypothesis testing results.

Table 2 Validity and Reliability of the Instruments.

\begin{tabular}{|l|l|l|l|l|l|l|}
\hline $\begin{array}{l}\text { Variabl } \\
\text { e }\end{array}$ & $\begin{array}{l}\text { Ite } \\
\mathbf{m}\end{array}$ & $\begin{array}{l}\text { Fact } \\
\text { or } \\
\text { loadi } \\
\text { ng }\end{array}$ & $\begin{array}{l}\text { Rema } \\
\text { rks }\end{array}$ & CR & $\begin{array}{l}\text { AV } \\
\mathbf{E}\end{array}$ & $\begin{array}{l}\text { Rema } \\
\text { rks }\end{array}$ \\
\hline $\begin{array}{l}\text { Laernin } \\
\text { g Goal }\end{array}$ & LO & 0,63 & Valid & 0,8 & 0,5 & $\begin{array}{l}\text { Reliab } \\
\text { le }\end{array}$ \\
\cline { 2 - 5 } $\begin{array}{l}\text { Orienta } \\
\text { tion }\end{array}$ & LO & 0,76 & Valid & & 21 & \\
\hline
\end{tabular}




\begin{tabular}{|c|c|c|c|c|c|c|}
\hline & $\begin{array}{l}\text { LO } \\
\text { G5 }\end{array}$ & $\begin{array}{l}0,73 \\
2\end{array}$ & Valid & & & \\
\hline & LO & 0,73 & Valid & & & \\
\hline & G4 & 6 & & & & \\
\hline & LO & 0,75 & Valid & & & \\
\hline & G2 & 5 & & & & \\
\hline & $\begin{array}{l}\mathrm{LO} \\
\mathrm{G} 1\end{array}$ & $\begin{array}{l}0,70 \\
1\end{array}$ & Valid & & & \\
\hline \multirow{7}{*}{$\begin{array}{l}\text { Mange } \\
\text { ment } \\
\text { Support }\end{array}$} & MS & 0,77 & Valid & \multirow{7}{*}{$\begin{array}{l}0,8 \\
95\end{array}$} & \multirow{7}{*}{$\begin{array}{l}0,6 \\
31\end{array}$} & \multirow{7}{*}{$\begin{array}{l}\text { Reliab } \\
\text { le }\end{array}$} \\
\hline & 5 & 8 & & & & \\
\hline & MS & 0,77 & Valid & & & \\
\hline & MS & 0,86 & Valid & & & \\
\hline & 3 & 9 & & & & \\
\hline & $\begin{array}{l}\text { MS } \\
2\end{array}$ & $\begin{array}{l}0,82 \\
9\end{array}$ & Valid & & & \\
\hline & MS & $\begin{array}{l}0,71 \\
2\end{array}$ & Valid & & & \\
\hline \multirow{9}{*}{$\begin{array}{l}\text { Comput } \\
\text { er Self } \\
\text { Effican } \\
\text { cy }\end{array}$} & CS & 0,68 & Valid & \multirow{9}{*}{$\begin{array}{l}0,8 \\
92\end{array}$} & \multirow{9}{*}{$\begin{array}{l}0,5 \\
44\end{array}$} & \multirow{9}{*}{$\begin{array}{l}\text { Reliab } \\
\text { le }\end{array}$} \\
\hline & E7 & 8 & & & & \\
\hline & $\begin{array}{l}\text { CS } \\
\mathrm{E} 6\end{array}$ & $\begin{array}{l}0,84 \\
6\end{array}$ & Valid & & & \\
\hline & CS & 0,70 & Valid & & & \\
\hline & E5 & 7 & & & & \\
\hline & $\begin{array}{l}\mathrm{CS} \\
\mathrm{E} 4\end{array}$ & $\begin{array}{l}0,82 \\
9\end{array}$ & Valid & & & \\
\hline & $\begin{array}{l}\text { CS } \\
\text { E3 }\end{array}$ & $\begin{array}{l}0,71 \\
9\end{array}$ & Valid & & & \\
\hline & $\begin{array}{l}\text { CS } \\
\text { E2 }\end{array}$ & $\begin{array}{l}0,71 \\
8\end{array}$ & Valid & & & \\
\hline & $\begin{array}{l}\text { CS } \\
\mathrm{E} 1\end{array}$ & $\begin{array}{l}0,63 \\
0\end{array}$ & Valid & & & \\
\hline \multirow{4}{*}{$\begin{array}{l}\text { Enjoym } \\
\text { ent }\end{array}$} & E3 & $\begin{array}{l}0,91 \\
9\end{array}$ & Valid & \multirow[t]{4}{*}{$\begin{array}{l}0,9 \\
42\end{array}$} & \multirow{4}{*}{$\begin{array}{l}0,8 \\
45\end{array}$} & \multirow{4}{*}{$\begin{array}{l}\text { Reliab } \\
\text { le }\end{array}$} \\
\hline & E2 & 0,92 & Valid & & & \\
\hline & F1 & 3 & Volid & & & \\
\hline & El & $\begin{array}{l}0,91 \\
5\end{array}$ & valıd & & & \\
\hline \multirow{4}{*}{$\begin{array}{l}\text { Perceiv } \\
\text { ed } \\
\text { Ease of } \\
\text { Use }\end{array}$} & $\mathrm{PE}$ & 0,89 & Valid & \multirow{4}{*}{$\begin{array}{l}0,8 \\
96\end{array}$} & \multirow{4}{*}{$\begin{array}{l}0,7 \\
43\end{array}$} & \multirow{4}{*}{$\begin{array}{l}\text { Reliab } \\
\text { le }\end{array}$} \\
\hline & U3 & 0 & & & & \\
\hline & $\begin{array}{l}\text { PE } \\
\text { U2 }\end{array}$ & $\begin{array}{l}0,93 \\
0\end{array}$ & Valid & & & \\
\hline & $\begin{array}{l}\text { PE } \\
\text { U1 }\end{array}$ & $\begin{array}{l}0,75 \\
7\end{array}$ & Valid & & & \\
\hline \multirow{4}{*}{$\begin{array}{l}\text { Perceiv } \\
\text { ed } \\
\text { Usefuln } \\
\text { ess }\end{array}$} & $\begin{array}{l}\mathrm{PU} \\
4\end{array}$ & $\begin{array}{l}0,90 \\
0\end{array}$ & Valid & \multirow[t]{4}{*}{$\begin{array}{l}0,9 \\
53\end{array}$} & \multirow[t]{4}{*}{$\begin{array}{l}0,8 \\
72\end{array}$} & \multirow[t]{4}{*}{$\begin{array}{l}\text { Reliab } \\
\text { le }\end{array}$} \\
\hline & PU & 0,94 & Valid & & & \\
\hline & 2 & 4 & & & & \\
\hline & $\begin{array}{l}\text { PU } \\
1\end{array}$ & $\begin{array}{l}0,95 \\
7\end{array}$ & Valid & & & \\
\hline \multirow{4}{*}{$\begin{array}{l}\text { Intentio } \\
\mathrm{n} \text { to } \\
\text { Use }\end{array}$} & ITU & 0,86 & Valid & \multirow{4}{*}{$\begin{array}{l}0,9 \\
27\end{array}$} & \multirow{4}{*}{$\begin{array}{l}0,8 \\
08\end{array}$} & \multirow{4}{*}{$\begin{array}{l}\text { Reliab } \\
\text { le }\end{array}$} \\
\hline & 3 & 5 & & & & \\
\hline & $\begin{array}{l}\text { ITU } \\
2\end{array}$ & $\begin{array}{l}0,90 \\
8\end{array}$ & Valid & & & \\
\hline & $\begin{array}{l}\text { ITU } \\
1\end{array}$ & $\begin{array}{l}0,92 \\
3\end{array}$ & Valid & & & \\
\hline \multirow[t]{3}{*}{$\begin{array}{l}\text { Satisfa } \\
\text { ction }\end{array}$} & S5 & $\begin{array}{l}0,90 \\
3\end{array}$ & Valid & $\begin{array}{l}0,9 \\
29\end{array}$ & $\begin{array}{l}0,8 \\
14\end{array}$ & Reliab \\
\hline & S4 & $\begin{array}{l}0,88 \\
0\end{array}$ & Valid & & & \\
\hline & S3 & $\begin{array}{l}0,92 \\
3\end{array}$ & Valid & & & \\
\hline
\end{tabular}

Table 3 Hypothesis testing result

\begin{tabular}{|c|c|c|c|c|c|}
\hline $\begin{array}{l}\text { Hypothe } \\
\text { sis }\end{array}$ & $\begin{array}{c}\text { Pat } \\
\text { h }\end{array}$ & $\begin{array}{c}\text { Coeffici } \\
\text { ent }\end{array}$ & $\begin{array}{c}\mathbf{T} \\
\text { valu } \\
\text { e }\end{array}$ & $\begin{array}{c}P \\
\text { Val } \\
\text { ue }\end{array}$ & $\begin{array}{c}\text { Remar } \\
\text { ks }\end{array}$ \\
\hline $\mathrm{H} 1$ & $\begin{array}{l}\mathrm{LG} \\
\mathrm{O} \rightarrow \\
\mathrm{PE} \\
\mathrm{U}\end{array}$ & 0,391 & $\begin{array}{l}4,43 \\
6\end{array}$ & 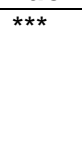 & $\begin{array}{l}\text { Accept } \\
\text { ed }\end{array}$ \\
\hline $\mathrm{H} 2$ & $\begin{array}{l}\mathrm{LG} \\
\mathrm{O} \rightarrow \\
\mathrm{PU}\end{array}$ & 0,281 & $\begin{array}{l}3,20 \\
5\end{array}$ & $\begin{array}{l}0,00 \\
1\end{array}$ & $\begin{array}{l}\text { Accept } \\
\text { ed }\end{array}$ \\
\hline H 3 & $\begin{array}{l}\text { MS } \\
\overrightarrow{P E} \\
\mathrm{PE} \\
\mathrm{U}\end{array}$ & 0,044 & $\begin{array}{l}0,84 \\
7\end{array}$ & $\begin{array}{l}0,39 \\
7\end{array}$ & $\begin{array}{l}\text { Declin } \\
\mathrm{e}\end{array}$ \\
\hline $\mathrm{H} 4$ & $\begin{array}{l}\text { MS } \\
\vec{P} \\
\mathrm{PU}\end{array}$ & 0,3 & $\begin{array}{l}5,13 \\
9\end{array}$ & $\star \star \star *$ & $\begin{array}{l}\text { Accept } \\
\text { ed }\end{array}$ \\
\hline H5 & $\begin{array}{l}\text { CS } \\
E \rightarrow \\
P E \\
U\end{array}$ & $-0,156$ & $-3,39$ & 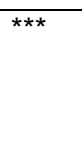 & $\begin{array}{l}\text { Declin } \\
\mathrm{e}\end{array}$ \\
\hline H 6 & $\begin{array}{l}\text { CS } \\
E \rightarrow \\
P U\end{array}$ & $-0,009$ & $\begin{array}{l}- \\
0,18 \\
8\end{array}$ & $\begin{array}{l}0,85 \\
1\end{array}$ & $\begin{array}{l}\text { Declin } \\
\mathrm{e}\end{array}$ \\
\hline H 7 & $\begin{array}{l}\mathrm{E} \rightarrow \\
\mathrm{PE} \\
\mathrm{U}\end{array}$ & 0,342 & $\begin{array}{l}7,20 \\
6\end{array}$ & 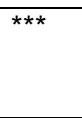 & $\begin{array}{l}\text { Accept } \\
\text { ed }\end{array}$ \\
\hline H8 & $\begin{array}{l}\mathrm{E} \rightarrow \\
\mathrm{PU}\end{array}$ & 0,509 & $\begin{array}{l}10,2 \\
76\end{array}$ & 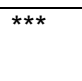 & $\begin{array}{l}\text { Accept } \\
\text { ed }\end{array}$ \\
\hline H9 & $\begin{array}{l}P E \\
\mathrm{U} \\
\rightarrow \mathrm{IT} \\
\mathrm{U}\end{array}$ & 0,143 & $\begin{array}{l}2,13 \\
5\end{array}$ & $\begin{array}{l}0,03 \\
3\end{array}$ & $\begin{array}{l}\text { Accept } \\
\text { ed }\end{array}$ \\
\hline H 10 & $\begin{array}{l}\text { PU } \\
\rightarrow \\
\text { ITU }\end{array}$ & 0,407 & $\begin{array}{l}6,88 \\
6\end{array}$ & 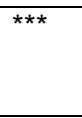 & $\begin{array}{l}\text { Accept } \\
\text { ed }\end{array}$ \\
\hline H 11 & $\begin{array}{l}\text { S } \overrightarrow{ } \\
\text { ITU }\end{array}$ & 0,275 & $\begin{array}{l}6,22 \\
1\end{array}$ & *** & $\begin{array}{l}\text { Accept } \\
\text { ed }\end{array}$ \\
\hline
\end{tabular}

In the learning goal orientation, the influence between goal orientation learning with perceived ease of use and perceived usefulness shows a positive and significant effect. In relation to perceived ease of use $(0.391 * * *)$, because these individuals enjoy challenging work and are willing to try hard when doing a task, it can be concluded that they tend to see e-learning features that are easy to use. With the perceived usefulness value of employees of the company that is classified as moderate, and the relationship between learning goal orientation towards perceived usefulness $(0.281 * *)$, it will be better to conclude that the learning opportunities offered by elearning can only be seen as something interesting for employees with higher learning goal orientation.

With the value of perceived ease of use in the company employees as high, and the relationship between management support to perceived ease of use that is not significant $(0.044)$, The support provided by management in encouraging employees to use e-learning

does not influence the employee's perspective, it will be easy to access e-learning. This can be influenced by the type of support the company provides. In the context 
of the company, management can probably not pay too much attention to employees in terms of providing information to help employees easily use e-learning. By system, the company has provided e-learning with certain modules that are user-friendly. My encouragement to access, management intensively conducts routine publications related to e-learning modules which are recommendations to be accessed by employees, for example, through the "My Learning Hour" program every Fri- day at $3 \mathrm{pm}$. However, management does not provide important information regarding how to access or use e-learning to make it easier for employees to use it. The perceived usefulness value of the company's employees is relatively moderate, and the relationship between management support for perceived usefulness is significantly positive $(0.300 * * *)$. The support provided by management in encouraging employees to use elearning influences employee perspectives will benefit when they use e-learning. This can be influenced by the type of support the company provides. In the context of the company, management pays attention to its employees to provide information related to benefits that employees can obtain if they use e-learning, although it is still general and not specific, such as including learning objectives in each recommended module.

The value of perceived ease of use on employees is high, and the relationship between computer self-efficacy to perceived ease of use is significantly negative $(-0.156$ $* * *)$. The more employees are confident in their ability to mobilize the motivation, resource cognitive, and actions needed to meet particular situational demands in learning, in this case especially e-learning, the more they feel e-learning is not easy to use. In addition, the perceived usefulness value of the employees is relatively low, and the relationship between computer self-efficacy to perceived usefulness is not significant (-0.009). Employees believe in their ability to mobilize the motivation, cognitive resources, and necessary actions to meet specific situational demands in learning. In this case, especially e-learning does not influence their perspective on the benefits of e-learning. This can be influenced by several things, one of which is the moderate value of computer self-efficacy. The value of computer self-efficacy that is being assumed to be a result of incompatibility with computer variables self-efficacy in the company, where the support of the availability of the latest up-dated systems and technologies and the existence of e-learning that have been quite long, tend to make most employees have a low perspective on computer self-efficacy.

The value of perceived ease of use on employees is high, and the relationship between enjoyment and perceived ease of use is significantly positive $\left(0.342^{* * *}\right)$. The more employees feel happy when doing activities using e-learning, the more they feel e-learning is easy to use. With the perceived usefulness value of employees classified as moderate, the re- relationship between enjoyment and usefulness is significantly positive (0.509 ***). The more employees feel happy when doing activities using e-learning, the more they feel e-learning benefits them.

The influence between perceived ease of use and intention to use shows significant positive results for employees $(0.143 * *)$. The higher the ease felt by employees in using e-learning, the higher their intention to use it. In addition, the influence between perceived usefulness and intention to use shows significant positive results for employees $(0.275 * * *)$. The higher the employee feels that using e-learning has benefits for their performance, the higher their intention to use e-learning. In the Technology Acceptance Model (TAM), the influence between perceived ease of use and perceived usefulness shows a significant positive effect on the intention to use.

\section{CONCLUSIONS}

\subsection{Conclusion}

Eleven conclusions were obtained from the research hypothesis test.

1) There is a significant positive influence between goal orientation learning and perceived ease of use, so $\mathrm{H} 1$ is accepted.

2) There is a significant positive effect between goal orientation learning and perceived usefulness, so $\mathrm{H} 2$ is accepted.

3) There is no significant positive influence between management support and perceived ease of use, so that $\mathrm{H} 3$ is rejected.

4) There is a significant positive influence between management support and perceived usefulness so that $\mathrm{H} 4$ is rejected.

5) There is no significant positive effect between computer self-efficacy and perceived ease of use, so $\mathrm{H} 5$ is rejected.

6) There is no significant positive effect between computer self-efficacy and perceived usefulness, so $\mathrm{H} 6$ is rejected.

7) There is a significant positive effect between enjoyment and perceived ease of use so that $\mathrm{H} 7$ is accepted.

8) There is a significant positive effect between enjoyment and perceived usefulness so that $\mathrm{H} 8$ is accepted.

9) There is a significant positive influence be- tween perceived ease of use and intention to use so that H9 is accepted. 
10) There is a significant positive influence between perceived usefulness and intention to use so that H10 is accepted.

11) There is a significant positive influence be- tween satisfaction and intention to use so thatH11 is accepted.

\subsection{Research limitations}

As long as the research took place, from the start of preparation, implementation, until after the research, researchers found several limitations of the study, including:

In this study, the respondent's research data have not been supported by qualitative comparisons that might be obtained through focus group discussions or direct in interviews with participants due to limited time in conducting research.

This study has not analyzed much of the results of hypothesis testing based on demographic data.

\subsection{Suggestion}

To increase the intention to use e-learning for employees, companies must increase the perceived ease of use and the perceived usefulness. In improving employee perceptions of perceived ease of use of elearning and perceived usefulness, the company can focus on efforts on several research variables which are found to have a significant effect on TAM, namely:

Learning goal orientation:

Provide information regarding how to use, help features on the system, tips \& tricks in accessing elearning.

Provide clear information related to programs in elearning, which explains the learning objectives intensively and regularly in order to foster the orientation of the learning objectives of the employees,

1. Management Support:

Provide delegates to managers from the team to develop related capabilities of team members through e-learning.

Provide specific learning catalogs so that employees can feel the benefits of e-learning more.

2. Enjoyment:

Conduct a small survey of employees at the XYZ company regarding what is considered pleasant from e-learning and what employeesexpect to get a pleasant feeling every time they access elearning.

Increase recognition by giving rewards for employees who diligently develop their abilities through e-learning and also use the wall of fame feature.
To be able to produce more in-depth research on the analysis of factors that influence the intention to use elearning, several things can be done in the next study, namely:

1. Subsequent research can look for research objects from more diverse industries.

To get more maximum results, the next study can identify indirect effects through mediators, which are used as research variables separately.

\section{REFERENCES}

[1] N. Bennett and G.J. Lemoine, "What a difference a word makes: Understanding threats to performance in a VUCA world," Business Horizons., vol. 57, no. 1, pp. 165-185, 2014.

[2] P.P.M.A.R. Heugens and M.W. Lander, "Structure! agency! (and other quarrels) - a meta analysis of institutional theories of organizations," Acad. Manag. J., vol. 52, no. 1, pp. 61-85, 2009.

[3] D. Schuchmann and S. Seufert, "Corporate learning in times of digital transformation: a conceptual framework and service portfolio for the learning function in banking organisations," Int. J. Adv. Corp. Learn., 2015.

[4] M.A. Weissenberger-Eibl, Innovationen und Lernen, Presentation at the F.PAK Kolloquium, München.

[5] R.A Noe, J.R. Hollenbeck, B.Gerhart, and P.M. Wright, Human Resources Management. New York: McGraw-Hill. 2015.

[6] P.A. Galagan, "The e-learning revolution," Training and Development., vol. 54, no. 12, pp. 24$30,2000$.

[7] K.G. Brown, “A field study of employee e-learning activity and outcomes," Hum. Resour. Dev. Q., vol. 16, no. 4, 2005.

[8] B.S. Bell and J. E. Federman, "E-learning in postsecondary education," Futur. Child., vol. 23, no. 1, pp. 165-185, 2013

[9] S. Sawang, C. Newton, and K. Jamieson, "Increasing learners' satisfaction/intention to adopt more e-learning," Educ. Train., vol. 55, no. 1, pp. 83-105, 2013.

[10] P. Zaharias and A. Poylymenakou, "Developing a usability evaluation method for e-learning applications: Beyond functional usability," Int. J. Hum. Comput. Interact., vol. 25, no. 1, pp. 75-98, 2009.

[11]H. J. Chen, 'Linking employees' e-learning system use to their overall job outcomes: An empirical 
study based on the IS success model," Comput. Educ., vol. 55, no, 4, pp. 1628-1639, 2010.

[12]D. Sachs and N. Hale, "Pace University's focus on student satisfaction with student services in online education," J. of Asynchronous Learning Network., vol. 7, no. 2, pp. 36-42, 2003.

[13] P.D. Chatzoglou, L. Sarigiannidis, E. Vraimaki, and A. Diamantidis, "Investigating Greek employees' intention to use web-based training," Comput. Educ.,vol. 53, no. 3, 2009.

[14]M. Esterhuyse, B. Scholtz, and D. Venter, "Intention to use and satisfaction of e-learning for training in the corporate context," Interdiscip. J. Information, Knowledge, Manag., vol. 11, pp. 347365, 2016.

[15] F.D. Davis, R.P. Bagozzi, and P.R. Warshaw, "User Acceptance of Computer Technology: A Comparison of Two Theoretical Models," Manage. Sci., vol. 35, no. 8, pp. 982-1003, 1989.

[16] P.R. Pintrich, "Multiple goals, multiple pathways: The role of goal orientation in learning and achievement," J. Educ. Psychol., no. 92, pp. 545$555,2000$.

[17] M.Y. Yi and Y. Hwang, "Predicting the use of webbased information systems: Self-efficacy, enjoyment, learning goal orientation, and the technology acceptance model," Int. J. Hum. Comput. Stud., vol. 59, no. 4, pp. 431-449, 2003.

[18] M. Igbaria, N. Zinatelli, P. Cragg, and A. L. M. Cavaye, "Personal computing acceptance factors in small firms: A structural equation model," MIS Q. Manag. Inf. Syst., 1997.

[19] D.R. Compeau and C.A. Higgins, "Computer selfefficacy: Development of a measure and initial test,” MIS Q. Manag. Inf. Syst., vol. 19, no. 2, pp. 189-211, 1995.

[20] G. Min, Y. Xu, and Y. Yu, “An Enhanced Technology Acceptance Model for Web-Based Learning," J. Inf. Syst. Educ., vol. 14, no. 4, pp. 365-374, 2004.

[21] V. Venkatesh, "Determinants of Perceived Ease of Use: Integrating Control, Intrinsic Motivation, and Emotion into the Technology Acceptance Model," Inf. Syst. Res., vol. 11, no. 4, pp. 342-365, 2000.

[22] V. Venkatesh and F. D. Davis, "A model of the antecedents of perceived ease of use: Development and test," Decis. Sci., vol. 27, no. 3, pp. 451-481, 1996.
[23] M. Koufaris and W. Hampton-sosa, "Customer Trust Online: Examinin the Role of the Web Site," Cis, 2002.

[24] J. W. Moon and Y. G. Kim, "Extending the TAM for a World-Wide-Web context," Inf. Manag., vol. 38, no. 4, pp. 217-230, 2001.

[25] V. Venkatesh, "Creation of favorable user perceptions: Exploring the role of intrinsic motivation,” MIS Q. Manag. Inf. Syst., vol. 23, no. 2, pp. 239-260, 1999.

[26] R. Agarwal and E. Karahanna, "Time flies when you're having fun: Cognitive absorption and beliefs about information technology usage," MIS Q. Manag. Inf. Syst., vol, 24, no. 4, pp. 665-694, 2000.

[27] M. Fishbein, and I. Azjen, Belief, attitude, intention and behavior: An introduction to theory and research. Reading, MA: Addison-Wesley. 1975.

[28] R.M. Cyert, R. and J.G. A behavior theory of the firm. Englewood Cliffs. NJ: Prentice-Hall. 1963.

[29]C.C. Chang, "Exploring the determinants of elearning systems continuance intention in academic libraries," Libr. Manag., vol. 34, no. 1/2, pp. 40-55, 2013.

[30] Hassanzadeh, F. Kanaani, and S. Elahi, “A model for measuring e-learning systems success in universities," Expert Syst. Appl., vol. 39, pp. 10959-10966, 2012.

[31] A.K.M.N. Islam, "The role of perceived system quality as educators' motivation to continue elearning system use," AIS Trans. Human-Computer Interact., vol. 4, no. 2, pp. 25-44, 2012.

[32] S. Petter, W. DeLone, and E. McLean, "Measuring information systems success: Models, dimensions, measures, and interrelationships," Eur. J. Inf. Syst., vol. 17, pp. 236-263, 2008.

[33] J.C. Roca, C.M. Chiu, and F.J. Martínez, "Understanding e-learning continuance intention: An extension of the Technology Acceptance Model,’ Int. J. Hum. Comput. Stud., vol. 64, pp. 683-696, 2006.

[34] G.J. Udo, K.K. Bagchi, and P.J. Kirs, "Using SERVQUAL to assess the quality of e-learning experience," Comput. Human Behav., pp. 12721283, 2011

[35] H. Mohammadi, “Investigating users' perspectives on e-learning: An integration of TAM and IS success model," Comput. Human Behav., vol. 45, pp. 359-374, 2015.

[36] J.F. Hair, W.C. Black, B.J. Babin, and R.E. Anderson, Multivariate Data Analysis. 7th Ed. New Jersey: Pearson Prentice Hall. 2010. 